\title{
Distribution and source of glycerol dialkyl glycerol tetraethers (GDGTs) and the applicability of GDGT-based temperature proxies in surface sediments of Prydz Bay, East Antarctica
}

\author{
Ruijuan Liu',2,3, Zhengbing Han², Jun Zhao², Haifeng Zhang ${ }^{2}$, Dong Li², Jianye Ren', \\ Jianming Pan $^{2}$ \& Haisheng Zhang ${ }^{2}$ \\ ${ }^{1}$ College of Marine Science and Technology, China University of Geosciences, Wuhan, China; \\ ${ }^{2}$ Key Laboratory of Marine Ecosystem Dynamics, Second Institute of Oceanography, \\ Ministry of Natural Resources, Hangzhou, China; \\ ${ }^{3}$ Zhejiang Ocean Monitoring and Forecasting Center, Hangzhou, China
}

\begin{abstract}
Reliable records of Southern Ocean seawater palaeotemperatures are important because this region plays a significant role in regulating global climate change. Biomarkers such as GDGT-based indices have been effectively used to reconstruct seawater temperatures. We analysed the composition and distribution of iGDGTs, OH-GDGTs and brGDGTs and calculated GDGT-based temperature indices in surface sediments from Prydz Bay, East Antarctica. Our results showed that iGDGTs, OH-GDGTs and brGDGTs are all produced in situ, with iGDGTs and OH-GDGTs mostly synthesized by Thaumarchaeota. Concentrations of iGDGTs, OH-GDGTs and brGDGTs showed similar spatial distributions and decreased from the continental shelf towards the deep ocean. The highest concentrations were in the inner bay, which is attributed to a combination of (1) bathymetry that reduces water exchange, (2) the Prydz Bay Gyre stabilizing the upper water column and (3) sea ice that releases archaea and bacteria. Among the temperature indices based on iGDGTs, OH-GDGTs and combinations therein, those based on OH-GDGTs showed the strongest correlation with seawater temperature. Some OH-GDGT-based indices (e.g., OH-0/ OHs, OH-1/OHs, OH-2/OHs and RI-OH') exhibited a stronger correlation with annual subsurface ocean temperature (100-200 m), which may be related to archaeal habitats and production mechanisms. Our study suggests that RI-OH' and $\mathrm{OH}-\mathrm{O} / \mathrm{OH}$ could be used as indicators of annual subsurface ocean temperature in Antarctic marginal seas.
\end{abstract}

\section{Keywords}

Biomarkers; archaea; seawater temperature; palaeotemperature indices; Antarctic marginal seas

\author{
Correspondence \\ Jianming Pan, Key Laboratory of Marine \\ Ecosystem Dynamics, Second Institute of \\ Oceanography, Ministry of Natural Resources, \\ 36 Baochu North Road, Hangzhou 310012, \\ China.E-mail:.jmpan@sio.org.cn

\begin{abstract}
Abbreviations
ADZ: Antarctic Divergence Zone $\mathrm{APCl}$ : atmospheric pressure chemical ionization

ASC: Antarctic Slope Current brGDGT: branched GDGT

CDW: circumpolar deep water $\mathrm{CO}_{2}$ : carbon dioxide

CoC: Antarctic Coastal Current Cren: crenarchaeol

Cren': crenarchaeol isomer GDGT: glycerol dialkyl glycerol tetraether IGDGT: isoprenoid GDGT mCDW: modified circumpolar deep water ODV: Ocean Data View version 4.7.3 software package

OH-GDGT: hydroxylated isoprenoid GDGT

RI-OH': ring index of OH-GDGTS

SOT: subsurface ocean temperature

SST: sea-surface temperature

TEX $_{86}$ : tetraether index of tetraethers

consisting of 86 carbon atoms

TOC: total organic carbon

WOA13: World Ocean Atlas 13 version 2
\end{abstract}

To access the supplementary material, please visit the article landing page

\section{Introduction}

The Southern Ocean plays an important role in the global climate system (Rintoul et al. 2018). Overturning of Southern Ocean water regulates global exchanges of heat (Frölicher et al. 2015) and $\mathrm{CO}_{2}$ (Gruber et al. 2009) and supplies nutrients to lower latitudes (Sarmiento et al. 2004); therefore, the Southern Ocean strongly influences global climate change. Simultaneously, it is also sensitive to global climate change; for instance, Southern 
Ocean surface or upper water temperatures have risen and continue to rise because of global warming (Turner et al. 2014; Rintoul et al. 2018). Seawater temperature, as an important physical parameter, has become indispensable in the study of global climate change. It is significant for studying global $\mathrm{CO}_{2}$ flux as $p \mathrm{CO}_{2}$ can be reduced by cooling warm waters in subpolar regions (Takahashi et al. 2002), and it is also crucial for studies on ecosystem variations in polar marine environment because seawater temperature and sea-ice extent can together affect food sources, organismal growth and reproduction, and biogeochemical cycles (Doney et al. 2012). Reliable records of seawater temperature are essential for the reconstruction of climate changes and predictions for the future (Nurnberg 2000). To overcome the short time records from instrumental temperature measurements, biomarkers have been used to obtain temperature data indirectly (Sachs et al. 2013). As one of the most promising and widely applied organic geochemical biomarkers, GDGTs have been used to reconstruct seawater temperature from the tropics to the polar regions (Schouten et al. 2013).

GDGTs are cell membrane lipids that are biosynthesized by archaea and/or bacteria; they have been detected in most environments, including peat, soil and the ocean (Schouten et al. 2013). On the basis of structural differences, GDGTs are usually divided into iGDGTs and brGDGTs. Schouten et al. (2002) found that the number of cyclopentane rings in iGDGTs present in marine sediments varies with annual mean SST and proposed using $\mathrm{TEX}_{86}$ to reconstruct seawater temperatures. Kim et al. (2010) further proposed using $\mathrm{TEX}_{86}^{\mathrm{L}}$ and $\mathrm{TEX}_{86}^{\mathrm{H}}$ in environments below and above $15{ }^{\circ} \mathrm{C}$, respectively. Improvements in detection techniques allowed OH-GDGTs to be identified recently in marine subsurface sediments (Lipp \& Hinrichs 2009) and the structural diversity was recognized from tandem mass spectral fragmentation patterns (Liu, Summons et al. 2012). Subsequent studies reported that both the number of rings and the relative abundance of OH-GDGTs to total iGDGTs exhibit strong relationships with SST (Fietz et al. 2013; Huguet et al. 2013; Lü et al. 2015). In the Arctic Ocean, correlations between SST and $\mathrm{OH}$-GDGT-based indices were stronger than those between SST and TEX ${ }_{86}$ and its derivative TEX ${ }_{86}^{\mathrm{L}}$ (Fietz et al. 2013). The performance of OH-GDGT-based indices was also superior to $\mathrm{TEX}_{86}$ and $\mathrm{TEX}_{86}^{\mathrm{L}}$ in the reconstruction of temporal trends in glacial and interglacial temperatures in the sub-Antarctic Atlantic Ocean (Fietz et al. 2016). Lü et al. (2015) proposed using RI-OH' to trace cool polar SSTs, and this index has been applied to study glacialinterglacial environmental changes over the Yermak Plateau, close to the Arctic Ocean (Kremer et al. 2018). The applicability of $\mathrm{TEX}_{86}$ and TEX $\mathrm{T}_{86}^{\mathrm{L}}$ palaeothermometry in the Southern Ocean has been validated. GDGTs have been used to reconstruct Holocene surface water (Shevenell et al. 2011) and upper water column (depths of 0-200 m) temperatures over the western Antarctic Peninsula (Etourneau et al. 2013), as well as Holocene subsurface water temperatures over the eastern Antarctic continental margin (Kim et al. 2012). However, few studies of OH-GDGTs and OH-GDGT-based indices have been undertaken in the Southern Ocean and their applicability in relatively enclosed Antarctic shelf areas, such as the Ross Sea and Prydz Bay, needs to be examined.

Prydz Bay is the largest shelf sea on the East Antarctic margin (Harris et al. 1998). The average temperature is low and sea-ice coverage is seasonal (Smith et al. 1984). In their study on archaeal abundance and diversity $5 \mathrm{~m}$ below the sea ice in Prydz Bay, Ma et al. (2014) found Thaumarchaeota in sea ice and seawater and Euryarchaeota in seawater; they reported that the average archaeal abundance accounted for $14.7 \%$ of the total picoplankton abundance in seawater and $28.3,34.7$ and $6.6 \%$ in the top, middle and bottom layers, respectively, of sea ice. Therefore, GDGTs produced by archaea in upper water masses are likely present in Prydz Bay sediments and would provide information about the environment in which the archaea developed. In this study, we evaluated the potential of OH-GDGTs as indicators of seawater temperature in Antarctic marginal seas. Surface sediments from the continental shelf and deep ocean area of Prydz Bay were analysed to determine the composition, distribution and potential sources of GDGTs, including iGDGTs, OH-GDGTs and brGDGTs.

\section{Material and methods}

\section{Study area}

Prydz Bay has a surface area of about $80000 \mathrm{~km}^{2}$ and is located in the Indian sector of the Southern Ocean between approximately $65^{\circ} \mathrm{E}$ and $80^{\circ} \mathrm{E}$ (Taylor $\&$ McMinn 2002). Its southern apex is connected to the Amery Ice Shelf/Lambert Glacier and its northern boundary extends to the continental slope break $\left(67^{\circ} \mathrm{S}\right)$. Fram Bank and Four Ladies Bank are on the western and eastern sides of the bay, respectively. These shallow banks form a spatial barrier to water exchange between the bay and the deep ocean (Smith \& Treguer 1994). The inner bay is a basin with a water depth of about $800 \mathrm{~m}$. The offshore open ocean, which lies to the north of the bay, is about $3000 \mathrm{~m}$ deep. In the surface ocean around Prydz Bay, the CoC and ASC flow westward, the Antarctic Circumpolar Current flows eastward, and cyclonic circulation is found in the Prydz Bay Gyre and in the vicinity of the ADZ (Smith et al. 1984; Vaz \& Lennon 1996; Taylor \& McMinn 2002; Yabuki et al. 2006; Williams et al. 2016). Prydz Bay is also 
characterized by seasonal sea-ice change. Sea ice expands to approximately $58^{\circ} \mathrm{S}$ in austral winter and retreats to the continental shelf in austral summer, although some multi-year ice may exist in coastal areas (Smith \& Treguer 1994; Worby et al. 1998).

\section{Samples}

Sixteen marine surface sediment samples from Prydz Bay were collected using a stainless steel box sampler during the 29th Chinese Antarctic Expedition in the austral summer of 2013. After collection, all samples were stored at $-20{ }^{\circ} \mathrm{C}$ and then freeze-dried in the laboratory until analysis. The samples were distributed over a broad range of geographic zones (Wang et al. 2015), including the inner bay, banks and deep-ocean regions (Fig. 1). The sedimentation rates in the inner bay and banks range from 0.47 to $1.88 \mathrm{~mm} / \mathrm{yr}$ (average of $1.06 \mathrm{~mm} / \mathrm{yr}$ ) (Yu et al. 2009); therefore, the surface sediments represent years to decades. Although sedimentation rates are generally lower in the deep ocean, the surface sediments here represent a few hundreds of years at most (Müller et al. 1998;
Roquet et al. 2014; Wu et al. 2017). Therefore, calibration scatter caused by differences in time is acceptable for temperature reconstructions on a geological time scale.

\section{Analytical procedures}

A portion of each sample (5-10 g) was used for GDGT analysis. The GDGTs were extracted using an accelerated solvent extractor (Dionex ASE 350, Thermo Fisher), according to the following protocol (Ho et al. 2014): heating for $5 \mathrm{~min}$ at $100{ }^{\circ} \mathrm{C}$, static time of $10 \mathrm{~min}$ and three cycles with a solvent mixture of dichloromethane:methanol $(9: 1, v / v)$. Prior to the extraction, the internal standard $\mathrm{C}_{46}$ GDGT $(0.4384 \mu \mathrm{g} /$ sample) was added. After extraction, the total lipid extracts were fractionated by open activated silica column $(0.8 \mathrm{~cm}$ inside diameter, volume $5 \mathrm{~mL}$ ) preconditioned with $n$-hexane $(10 \mathrm{~mL})$ into apolar and polar fractions using $n$-hexane $(8 \mathrm{~mL})$ and dichloromethane:methanol (10 mL; 95:5, v/v), respectively, as eluents (Kremer et al. 2018). The GDGTs were included in the polar fractions. All of the polar fractions were blow-dried under nitrogen, redissolved in a solvent

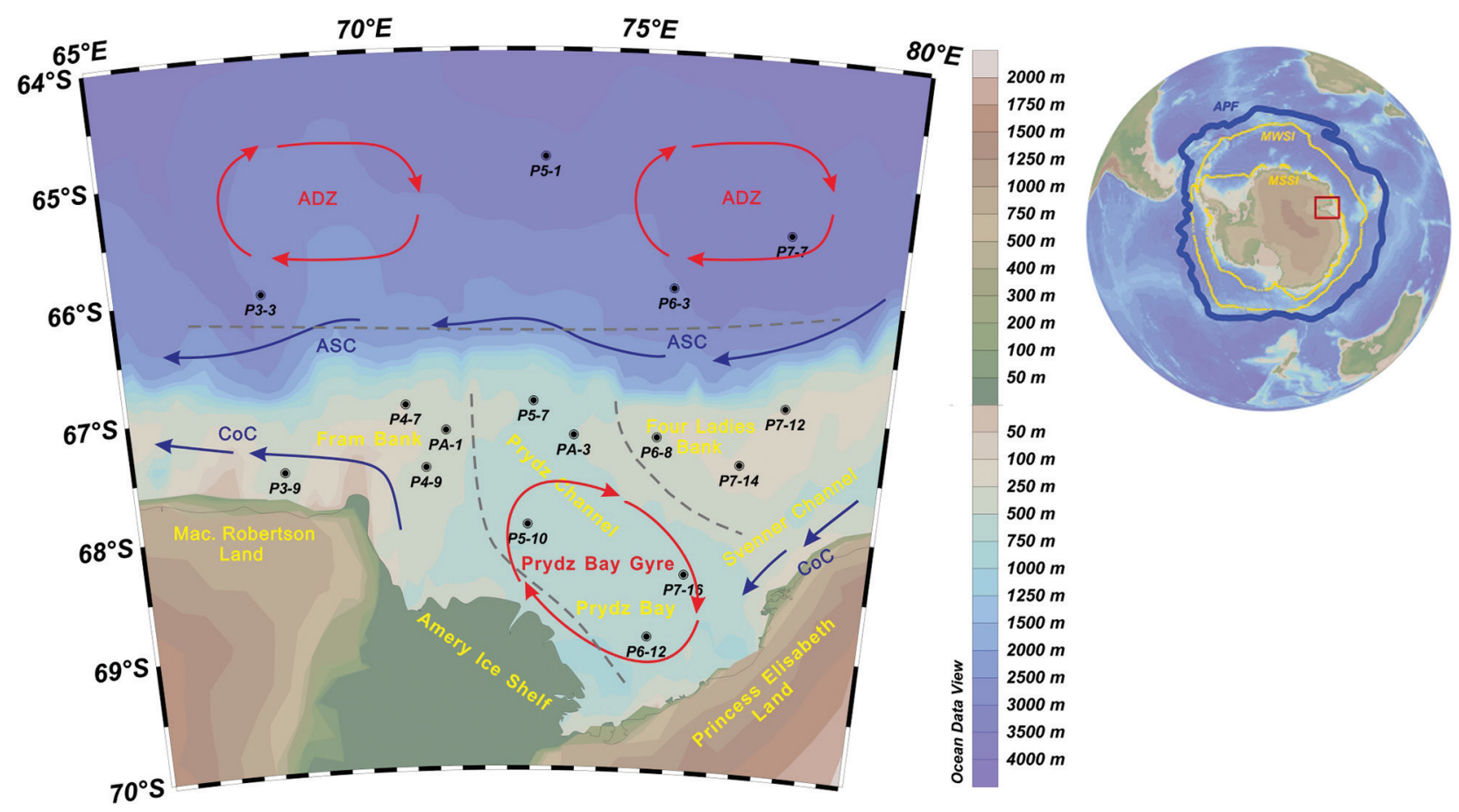

Fig. 1 Sampling sites and environmental setting of Prydz Bay, East Antarctica. The Prydz Bay area is outlined by a red rectangle on the inset map. The blue lines represent the COC and ASC. The red circles denote the Prydz Bay Gyre and ADZ. All of the currents are based on Cooper \& O'Brien (2004) and Wu et al. (2017). According to surface sediment characteristics (Wang et al. 2015), the light grey dotted lines indicate three sections in our study area: the inner bay, banks and deep ocean. The topographic map was generated using ODV (Schlitzer 2015). All of the sample sites are represented as black dots. All of the surface sediments were collected using a box sampler during the 29th Chinese Antarctic Expedition in the 2013 austral summer. In the overview map, the deep blue shaded area denotes the Antarctic Polar Front generated by ODV. The yellow line represents the modern winter sea-ice edge and modern summer sea-ice edge. The sea-ice extent data were obtained from the US National Snow and Ice Data Centre. 
mixture of $n$-hexane:isopropanol ( $1 \mathrm{~mL} ; 95: 5, \mathrm{v} / \mathrm{v}$ ) and filtered through a $0.45-\mu \mathrm{m}$ polytetrafluoroethylene filter.

Compound identification was performed with ultra- performance liquid chromatography (Acquity, Waters) coupled with APCI mass spectrometry (Xevo TQ MS, Waters) equipped with an HSS Cyano column $(2.1 \times 100 \mathrm{~mm}, 1.8 \mu \mathrm{m})$. The APCI source was operated in positive ion mode with conditions as follows: $2.2 \mu \mathrm{A}$ corona current, $1.5 \mathrm{kV}$ corona voltage, $33 \mathrm{~V}$ cone voltage, $3 \mathrm{~V}$ extractor voltage, $100 \mathrm{~L} / \mathrm{Hr}$ cone gas, $150{ }^{\circ} \mathrm{C}$ source temperature, $550{ }^{\circ} \mathrm{C}$ probe temperature, $1000 \mathrm{~L} / \mathrm{Hr}$ desolvation gas and $0.15 \mathrm{~mL} / \mathrm{min}$ crash gas. GDGTs were eluted using El (hexane):E2 (hexane:isopropanol) (99:1, v/v), with $0.1 \%$ isopropanol for $0.5 \mathrm{~min}$ (flow rate: $0.2 \mathrm{~mL} /$ $\mathrm{min})$, then a linear gradient up to $0.5 \%$ over $0.6 \mathrm{~min}$ ( $3.5 \mathrm{~min}$ isothermal), followed by up to $1 \%$ in $1.4 \mathrm{~min}$ ( $2 \mathrm{~min}$ isothermal) and finally to $0.1 \%$ (4 min isothermal) (Kremer et al. 2018).

Selected ion monitoring was used to scan $[\mathrm{M}+\mathrm{H}]^{+}$of the iGDGTs including GDGT-0, GDGT-1, GDGT-2, GDGT3, Cren and Cren' at $\mathrm{m} / \mathrm{z}$ of 1302, 1300, 1298, 1296, 1292 and 1292, respectively. The brGDGTs, including GDGTs IIIa, GDGTs IIIb, GDGTs IIIc, GDGTs IIa, GDGTs
IIb, GDGTs IIc, GDGTs Ia, GDGTs Ib and GDGTs Ic, were scanned at 1050, 1048, 1046, 1036, 1034, 1032, 1022, 1020 and $1018 \mathrm{~m} / \mathrm{z}$, respectively, and OH-GDGT-0 (OH$0)$, OH-GDGT-1 (OH-1) and OH-GDGT-2 (OH-2) were scanned at 1318, 1316 and $1314 \mathrm{~m} / \mathrm{z}$, respectively (Fig. 2). Peak area integration of OH-GDGTs also comprised in-source fragmentation products of OH-GDGTs (1300, 1298 and 1296 m/z) (Liu, Lipps et al. 2012; Lü et al. 2015). Quantification of the GDGTs was carried out using $\mathrm{C}_{46}$ GDGT as an internal standard.

\section{Seawater temperature}

We extracted seawater temperatures from WOAl3 on a $1 / 4^{\circ}$ grid resolution (Locarnini et al. 2013). Annual and seasonal mean climatological seawater temperatures from 1955 to 2012 were averaged over different depths to examine the applicability of temperature indices for the austral autumn (April-June), winter (July-September), spring (October-December) and summer (JanuaryMarch). Since the water depths of some stations in the banks zone were just more than $200 \mathrm{~m}$, we used $200 \mathrm{~m}$ as the deepest layer in the discussion. The selected water
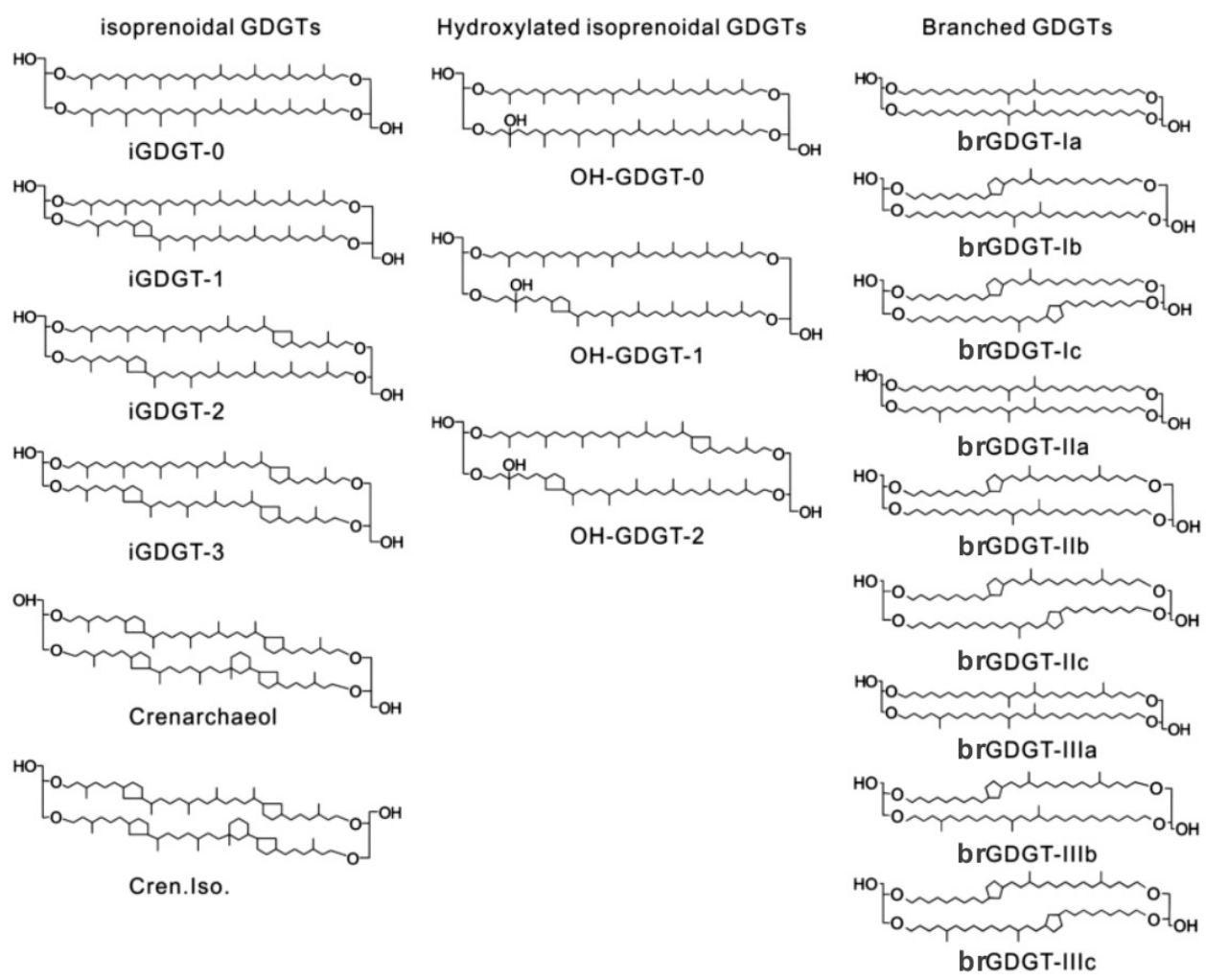

Fig. 2 Structures of iGDGTs, OH-GDGTs and brGDGTs. 
depths were $0,10,20,30,50,75,100,125,150,175$ and $200 \mathrm{~m}$. The extracted seawater temperatures were from the same latitude and longitude or the nearest degree to each surface sediment site.

\section{Calculation and statistical analysis}

All GDGT data were normalized to TOC to eliminate possible effects of organic matter diagenesis (Fietz et al. 2012). The ratios of GDGT-0/Cren and brGDGT-IIIa/IIa were used to identify the potential sources of iGDGTs and brGDGTs, respectively (Blaga et al. 2009; Xiao et al. 2016). Most of the GDGT-based temperature indices used in this study are listed in Table 1. The applicability of fractional abundances of OH-GDGTs (OH-0/ $\mathrm{OHs}, \mathrm{OH}-1 / \mathrm{OHs}$ and $\mathrm{OH}-2 / \mathrm{OHs}$ ) as palaeotemperature indices was also tested. Statistical analyses were performed using IBM SPSS 19.0. Significant differences between samples were defined using the Pearson correlation coefficient. Figures were drawn using Origin
9.1, ODV (Schlitzer 2015), CorelDRAW X8, ArcGIS 10.2 and $\mathrm{R}$ programming language software 3.5.2 (R Core Team 2018).

\section{Results}

\section{Composition and distribution of GDGTs}

We found iGDGTs, OH-GDGTs and brGDGTs in all sediment samples from Prydz Bay. Concentrations of iGDGTs, OH-GDGTs and brGDGTs ranged from 410 to 7972, 50 to 1528 and 59 to $383 \mu \mathrm{g} / \mathrm{g}$ TOC, respectively, and the average concentrations \pm standard deviation were $2318 \pm 1976$, $504 \pm 439$ and $182 \pm 96 \mu \mathrm{g} / \mathrm{g}$ TOC, respectively (Fig. 3). The iGDGTs clearly dominated, accounting for $68.5-86.8 \%$ of total GDGTs, while OH-GDGTs and brGDGTs represented $7.4-23.1 \%$ and $2.6-15.2 \%$, respectively. The maximum ratio $(23.1 \%)$ of OH-GDGTs to total iGDGTs was slightly higher than that $(20.5 \%)$ proposed by Huguet et al. (2013) for high latitudes. The highest concentrations of iGDGTs, OH-GDGTs and brGDGTs were found at stations P5-10 and P6-12,

Table 1 GDGT-based indices used in this study.

\begin{tabular}{|c|c|c|}
\hline Number & Equation & Reference \\
\hline 1 & $\mathrm{TEX}_{86}=\frac{\left([\mathrm{GDGT}-2]+[\mathrm{GDGT}-3]+\left[\mathrm{Cren}^{\prime}\right]\right)}{\left([\mathrm{GDGT}-1]+[\mathrm{GDGT}-2]+[\mathrm{GDGT}-3]+\left[\text { Cren }^{\prime}\right]\right.}$ & Schouten et al. 2002 \\
\hline 2 & $\mathrm{TEX}_{86}^{\mathrm{L}}=\log \left(\frac{[\mathrm{GDGT}-2]}{[\mathrm{GDGT}-1]+[\mathrm{GDGT}-2]+[\mathrm{GDGT}-3]}\right)$ & Kim et al. 2010 \\
\hline 3 & $\mathrm{OH} \%=\frac{\sum \mathrm{OH}-\mathrm{GDGTS}}{\sum \mathrm{OH}-\mathrm{GDGTS}+\sum \mathrm{iGDGTs}} \times 100$ & Huguet et al. 2013 \\
\hline 4 & $\mathrm{OH}-\mathrm{TEX}_{86}=\frac{[\mathrm{GDGT}-2]+[\mathrm{GDGT}-3]+\left[\mathrm{Cren}^{\prime}\right]}{\sum \mathrm{OH}-\mathrm{GDGTS}+[\mathrm{GDGT}-1]+[\mathrm{GDGT}-2]+[\mathrm{GDGT}-3]+\left[\mathrm{Cren}^{\prime}\right]}$ & Huguet et al. 2013 \\
\hline 5 & $\mathrm{OH}^{\mathrm{L}}=\log _{10}\left[\frac{\sum \mathrm{OH}-\mathrm{GDGTS}}{\sum \mathrm{OH}-\mathrm{GDGTS}+\sum \mathrm{iGDGTS}}\right]$ & Fietz et al. 2016 \\
\hline 6 & $\mathrm{OH}^{\mathrm{C}}=\frac{[\mathrm{GDGT}-2]+[\mathrm{GDGT}-3]+\left[\mathrm{Cren}^{\prime}\right]-[\mathrm{OH}-\mathrm{GDGT}-0]}{[\mathrm{GDGT}-1]+[\mathrm{GDGT}-2]+[\mathrm{GDGT}-3]+\left[\mathrm{Cren}^{\prime}\right]+\sum \mathrm{OH}-\mathrm{GDGTs}}$ & Fietz et al. 2016 \\
\hline 7 & $\mathrm{RI}-\mathrm{OH}^{\prime}=\frac{[\mathrm{OH}-\mathrm{GDGT}-1]+2 \times[\mathrm{OH}-\mathrm{GDGT}-2]}{[\mathrm{OH}-\mathrm{GDGT}-0]+[\mathrm{OH}-\mathrm{GDGT}-1]+[\mathrm{OH}-\mathrm{GDGT}-2]}$ & Lü et al. 2015 \\
\hline 8 & $\mathrm{OH}-\mathrm{O} / \mathrm{OHs}=\frac{[\mathrm{OH}-\mathrm{GDGT}-0]}{[\mathrm{OH}-\mathrm{GDGT}-0]+[\mathrm{OH}-\mathrm{GDGT}-1]+[\mathrm{OH}-\mathrm{GDGT}-2]}$ & Lü et al. 2015 \\
\hline 9 & $\mathrm{OH}-1 / \mathrm{OHs}=\frac{[\mathrm{OH}-\mathrm{GDGT}-1]}{[\mathrm{OH}-\mathrm{GDGT}-0]+[\mathrm{OH}-\mathrm{GDGT}-1]+[\mathrm{OH}-\mathrm{GDGT}-2]}$ & Lü et al. 2015 \\
\hline 10 & $\mathrm{OH}-2 / \mathrm{OHs}=\frac{[\mathrm{OH}-\mathrm{GDGT}-2]}{[\mathrm{OH}-\mathrm{GDGT}-0]+[\mathrm{OH}-\mathrm{GDGT}-1]+[\mathrm{OH}-\mathrm{GDGT}-2]}$ & Lü et al. 2015 \\
\hline
\end{tabular}




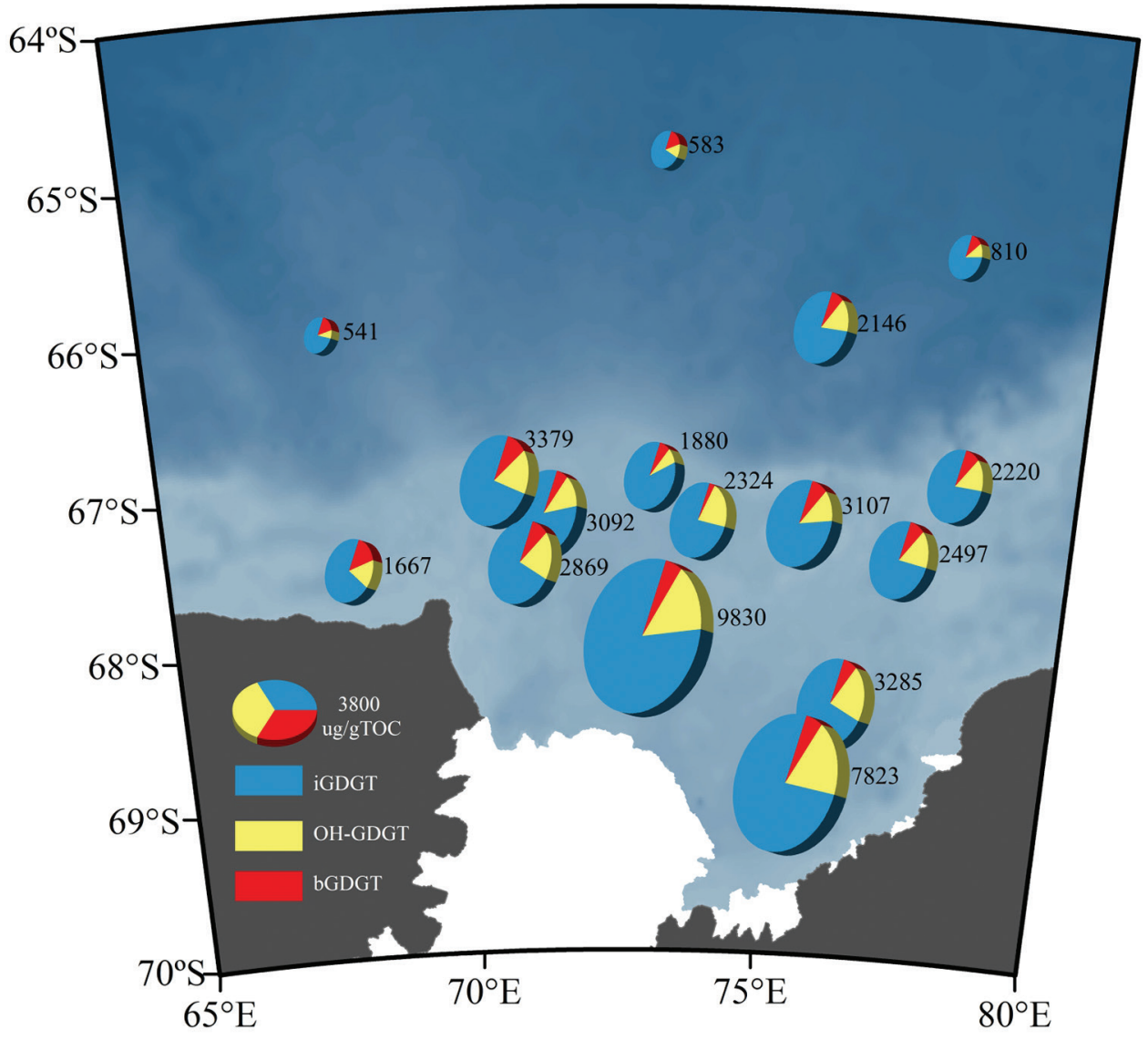

Fig. 3 Concentrations and distribution of iGDGTs, OH-GDGTs and brGDGTs in surface sediments of the study area ( $\mu$ g/g TOC). The size of the pie chart is proportional to total GDGTs: the larger the pie chart, the higher the total GDGT concentration. The ratios of blue, yellow and red sections denote relative fractional abundances of iGDGTs, OH-GDGTs and brGDGTs to total GDGTs, respectively. The black numbers represent the concentrations of total GDGTs.

which were in the centre and south-eastern corner of the inner bay, respectively. The lowest concentrations of iGDGTs and OH-GDGTs were found at station P3-3, which was located in the deep ocean, and the lowest concentration of brGDGTs was found at station PA-3 in Prydz Channel. These results indicate that concentrations of iGDGTs, OH-GDGTs and brGDGTs show similar spatial distributions and decrease from the continental shelf towards the deep ocean.

\section{Relative fractional abundances of GDGTs}

All fractions (types) of GDGTs were detected and quantified, although the concentrations of some fractions were very low (Supplementary Table S1). The dominant iGDGTs were GDGT-0 and Cren, which accounted for 36-73\% and $25-60 \%$, respectively, of total iGDGTs, while the sum of GDGT- 1 to GDGT-3 only accounted for $4 \%$, on average, of total iGDGTs. The dominant OH-GDGT was OH-0, which accounted for $80-94 \%$ of total OH-GDGTs. The dominant brGDGTs were GDGT-III (including GDGT-IIIa,

\section{6}

IIIb and IIIc), which accounted for $30-65 \%$ of total brGDGTs, and GDGT-II, which accounted for $19-54 \%$ of total brGDGTs. Differences in fractional abundances of various brGDGTs on the continental shelf and in the deep ocean were observed; the relative abundance of GDGT-IIIa was high in the deep ocean, while that of GDGT-IIb was high on the continental shelf.

\section{GDGT-based indices}

Ratios of GDGT-0/Cren ranged from 0.6 to 1.9, except at station P5-10, where it reached 2.9 (Fig. 4a). Ratios of brGDGT-IIIa/brGDGT-IIa ranged from 1.8 to 4.9 , with an average of 3.1 (Fig. 4b). The GDGT-based indices, including $\mathrm{TEX}_{86^{\prime}} \mathrm{TEX}_{86^{\prime}}^{\mathrm{L}} \mathrm{OH} \%, \mathrm{OH}-\mathrm{TEX}_{86^{\prime}} \mathrm{OH}^{\mathrm{L}}, \mathrm{OH}^{\mathrm{C}}$ and RI-OH', were calculated from surface sediment samples from Prydz Bay (Supplementary Table S2). TEX ${ }_{86}$ ranged from 0.34 to 0.46 and $\mathrm{TEX}_{86}^{\mathrm{L}}$ ranged from -0.79 to -0.62 . The

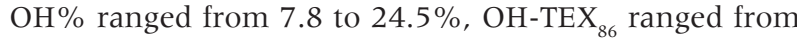
0.04 to $0.13, \mathrm{OH}^{\mathrm{L}}$ ranged from -1.11 to $-0.61, \mathrm{OH}^{\mathrm{C}}$ ranged 

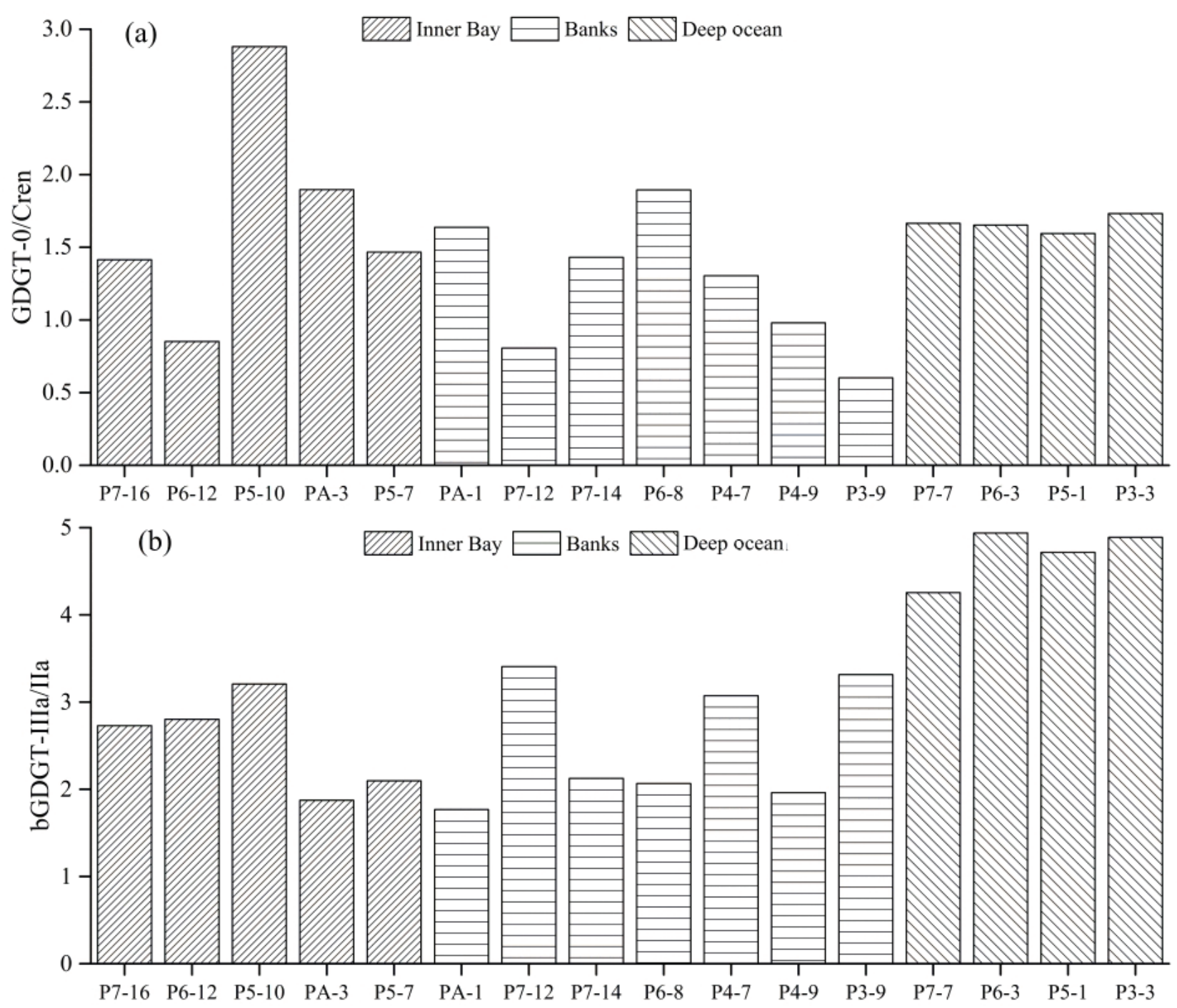

Fig. 4 Ratios of GDGT-0/Cren and brGDGT-IIla/lla from all stations in our study area, including the inner bay, banks and deep ocean.

from -0.80 to -0.37 and RI-OH' ranged from 0.07 to 0.36 . The $\mathrm{OH}-0 / \mathrm{OHs}$ ranged from 0.72 to 0.94 , OH-1/OHs ranged from 0.05 to 0.19 and $\mathrm{OH}-2 / \mathrm{OHs}$ ranged from 0.01 to 0.08 .

\section{Discussion}

\section{Potential sources of GDGTs and factors controlling distribution}

Potential sources of iGDGTs. The iGDGTs are categorized into GDGT-0, GDGT-1, GDGT-2, GDGT-3, Cren and Cren' depending on the number of cyclopentane moieties (Fig. 2) (Schouten et al. 2013). In our study area, GDGT-0 and Cren were the two dominant types, accounting for $36-73 \%$ and $25-60 \%$ of iGDGTs, respectively. Cren is mainly produced by Thaumarchaeota (Sinninghe Damsté et al. 2002; Schouten et al. 2013), which are more abundant than Euryarchaeota in Prydz Bay (Ma et al. 2014). Thaumarchaeota may therefore be an important source of Cren. The Pearson correlation coefficients between concentrations of every two fractions were high $(0.66<r<0.98, p<0.01)$, suggesting that all fractions were derived from the same source. Therefore, Thaumarchaeota are also an important source of iGDGTs overall. In addition, in Thaumarchaeota the ratio of GDGT-0/ Cren typically varies between 0.2 and 2 (Schouten et al. 2002), while a GDGT-0/Cren value $>2$ indicates other origins for GDGT-0 (Blaga et al. 2009; Schouten et al. 2013). In our study area, the GDGT-0/Cren ranged from 0.6 to 1.9 , indicating that Thaumarchaeota are likely the main source of iGDGTs. The exception was station P5-10, 
where GDGT-0/Cren reached 2.9, suggesting that other archaea, such as Euryarchaeota, could be another source of GDGT-0 at station of P5-10. Overall, Thuamarchaeota are most likely the main source of iGDGTs; however, small amounts contributed by other archaea could not be excluded.

Potential sources of OH-GDGTs. OH-GDGTs are a newly discovered type of iGDGTs. They have one to two additional hydroxyl groups on the alkyl chain and have higher polarity than iGDGTs (Liu, Summons et al. 2012). Similar to iGDGTs, OH-GDGTs are categorized into $\mathrm{OH}-0$, $\mathrm{OH}-\mathrm{l}$ and $\mathrm{OH}-2$ (Fig. 2). In Prydz Bay surface sediments, we found a strong linear relationship between iGDGT and OH-GDGT concentrations $\left(R^{2}=0.88, p<0.01\right)$ and between $\mathrm{OH}-0$ and Cren concentrations $\left(R^{2}=0.88\right.$, $p<0.01)$. According to previous studies in Nordic seas (Fietz et al. 2013) and Baltic Sea (Kaiser \& Arz 2016) surface sediments, the positive relationship between iGDGTs and OH-GDGTs indicates that they may be produced by a common archaeal community source, and this could also be the case in our study area. Identification of OH-GDGT biological sources is complex because of the abundant diversity of archaeal communities (Teske \& Sørensen 2008). The dominant thaumarchaeotal group, Group 1.la Thaumarchaeota (Schouten et al. 2013) and the methanogenic Euryarchaeota Methanothermococcus thermolithotrophicus produce OH-GDGTs in marine environments (Liu, Lipps et al. 2012); however, OH-GDGTs are not present in Group 1.1b Thaumarchaeota (Schouten et al. 2013), but other unspecified Crenarchaeota or Euryarchaeota could also synthesize OH-GDGTs (Lü et al. 2015). Hence, similar to iGDGTs, Thaumarchaeota might be the main source of OH-GDGTs, while small amounts could also be produced by other archaea.

Potential sources of brGDGTs. BrGDGT-IIIa/IIa in surface sediments from our study area ranged from 1.8 to 4.9 , with an average of 3.1 (Fig. $4 \mathrm{~b}$ ). In their global survey, Xiao et al. (2016) showed that the ratio of brGDGT-IIIa and brGDGT-IIa is generally less than 0.59 in soils and greater than 0.92 in marine sediments without significant terrestrial input, thereby allowing the provenance of brGDGTs to be determined. Our results were much higher than 0.92, suggesting that brGDGTs in our study area have a marine origin. In addition, the brGDGT-IIIa/IIa values were higher in the deep ocean than in the inner bay and banks.

Generally, brGDGTs are thought to be synthesized by soil bacteria (Sinninghe Damsté et al. 2000; Weijers et al. 2006). Investigations into sources of brGDGTs (Weijers et al. 2009) and aerobic Acidobacteria cultures (Sinninghe Damsté et al. 2011) indicated that Acidobacteria are a likely source of brGDGTs. Studies of marine sediments (Peterse et al. 2009) and lake water and sediments (Sinninghe Damsté et al. 2009; Tierney \& Russell 2009; Tierney et al. 2010) also reported in situ bacterial synthesis of brGDGTs. In marine sediments, in situ production is generally negligible compared with soil input (Peterse et al. 2009). However, around Prydz Bay, true soil influence is negligible because of the absence of fluvial input (Gasparon \& Matschullat 2006). Therefore, in our study area, brGDGTs might have been produced in situ and probably did not come from soil.

Factors controlling GDGT distribution. In our study area, iGDGT, OH-GDGT and brGDGT concentrations were highest on the continental shelf and decreased towards the deep ocean. There were strong correlations between iGDGT and OH-GDGT concentrations $\left(R^{2}=0.88\right.$, $p<0.01)$, brGDGT and iGDGT concentrations $\left(R^{2}=0.71\right.$, $p<0.01)$ and OH-GDGT and brGDGT concentrations $\left(R^{2}=0.72, p<0.01\right)$. All the GDGTs (iGDGTs, OH-GDGTs and brGDGTs) were likely produced in situ; therefore, GDGT abundances might be affected by the same factors. Depositional and preservation-related effects on organic matter were reduced through the normalization to TOC (Fietz et al. 2012). In addition, degradation differences between brGDGTs and iGDGTs from matrix protection seemed not to be a factor as all of the GDGTs were likely produced in the marine environment (Huguet et al. 2008). Hence, GDGT composition in surface sediments depends on the productivity of archaea and bacteria in the overlying water (Wang et al. 2013).

Bathymetry, the Prydz Bay Gyre and sea ice may explain the high abundance of GDGTs in the inner bay (stations P5-10 and P6-12). The closed Prydz Bay Gyre stabilizes the upper water column, while Four Ladies and Fram banks reduce water exchange with the deep ocean (Smith \& Treguer 1994; Sun et al. 2012). These characteristics benefit archaeal and bacterial productivity and organic matter sedimentation from the upper ocean. In the inner bay, sea ice melts early and in large quantities (Smith \& Treguer 1994), thereby releasing abundant amounts of previously trapped archaea and bacteria into Prydz Bay (Brinkmeyer et al. 2003; Cowie et al. 2011; Ma et al. 2014). In the deep ocean, an intensified ASC and upwelled CDW/mCDW might not be conductive to water stability (Smith et al. 1984; Meijers et al. 2010), which would affect the productivity of archaea and bacteria.

\section{Evaluation of GDGT-based SST indices}

Applicability of GDGT-based SST indices. Mean annual SST in our study area ranges from -1.56 to $-0.70{ }^{\circ} \mathrm{C}$, as determined from WOAl3 data. Despite the small variability in mean annual values, SST exhibits seasonal variability. SSTs are higher during the ice-free period in austral 


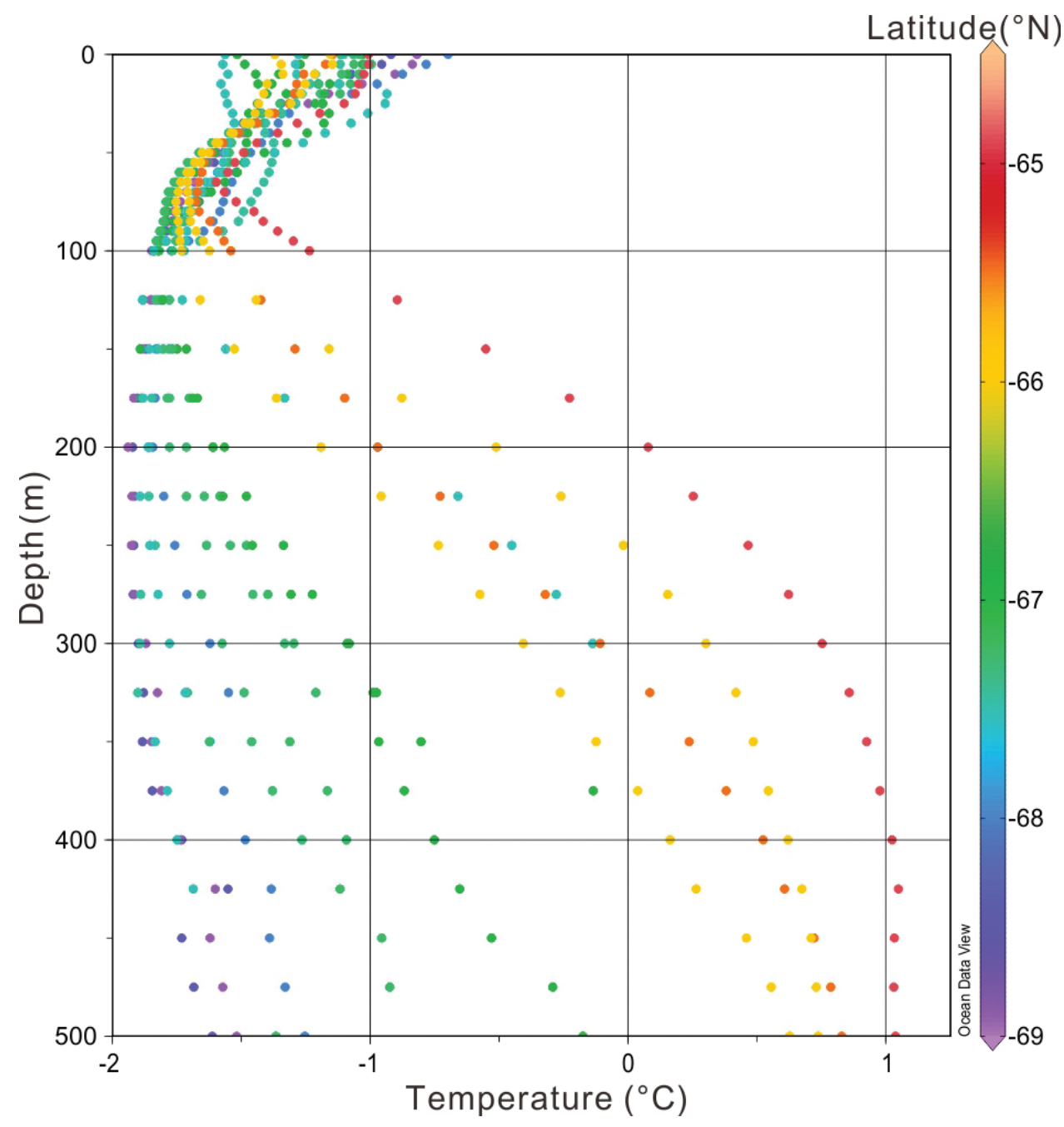

Fig. 5 Variations in seawater temperature with depth at all stations in our study area. Using the station location, we extracted seawater temperatures from the same or nearest sites at different depths from WOA13 on a $1 / 4^{\circ}$ grid resolution (Locarnini et al. 2013) and displayed the data using ODV (Schlitzer 2015).

summer and lower in other seasons when sea ice is present. There is a clear variation in seawater temperature with water depth, with temperatures decreasing from the surface to about $100 \mathrm{~m}$ and increasing between 100 and $500 \mathrm{~m}$ (Fig. 5).

As a result of in situ GDGT synthesis in our study area, sedimentary GDGTs can reflect environmental information (e.g., seawater temperature) of archaeal habitats. We examined the correlations between annual mean seawater temperature at different depths and various indices based on iGDGTs and OH-GDGTs to assess the applicability of these indices (Fig. 6). The widely used TEX ${ }_{86}$ and $\mathrm{TEX}_{86}^{\mathrm{L}}$ are more strongly correlated with annual SST than with SOT. However, Pearson's correlation coefficients were relatively low for both indices (Fig. 6), and SSTs reconstructed from $\mathrm{TEX}_{86}^{\mathrm{L}}$ (between -3.9 and $4.8^{\circ} \mathrm{C}$ ) differ from those reported in WOA13. In a study of global OH-GDGT distribution,
Huguet et al. (2013) showed that $\mathrm{OH} \%$ may increase from low latitudes to polar regions with decreasing temperature, and that relative abundances of surface sediment OH-GDGTs are significantly correlated with SSTs over a wide temperature range. However, we found no significant correlation between temperature and $\mathrm{OH} \%$ or $\mathrm{OH}^{\mathrm{L}}$ (Fig. 6). The sensitivity of $\mathrm{OH} \%$ may be too low over the narrow temperature range $\left(-2\right.$ to $\left.0{ }^{\circ} \mathrm{C}\right)$ found in our study area.

The OH-TEX ${ }_{86^{\prime}} \mathrm{OH}^{\mathrm{C}}, \mathrm{OH}-0 / \mathrm{OHs}, \mathrm{OH}-1 / \mathrm{OHs}, \mathrm{OH}-2 /$ OHs and RI-OH' are more strongly correlated with annual SOT (100-200 m) than with annual SST. Pearson's correlation coefficients between SOT and $\mathrm{OH}^{\mathrm{C}}$ and $\mathrm{OH}-\mathrm{TEX}_{86}$ were relatively low, while those between SOT and $\mathrm{OH}-0 / \mathrm{OHs}, \mathrm{OH}-1 / \mathrm{OHs}, \mathrm{OH}-2 / \mathrm{OH}$ and $\mathrm{RI}-\mathrm{OH}^{\prime}$ were higher (Fig. 6). These results suggest that fractional abundances of OH-GDGTs are more sensitive than iGDGTs to seawater temperature. 


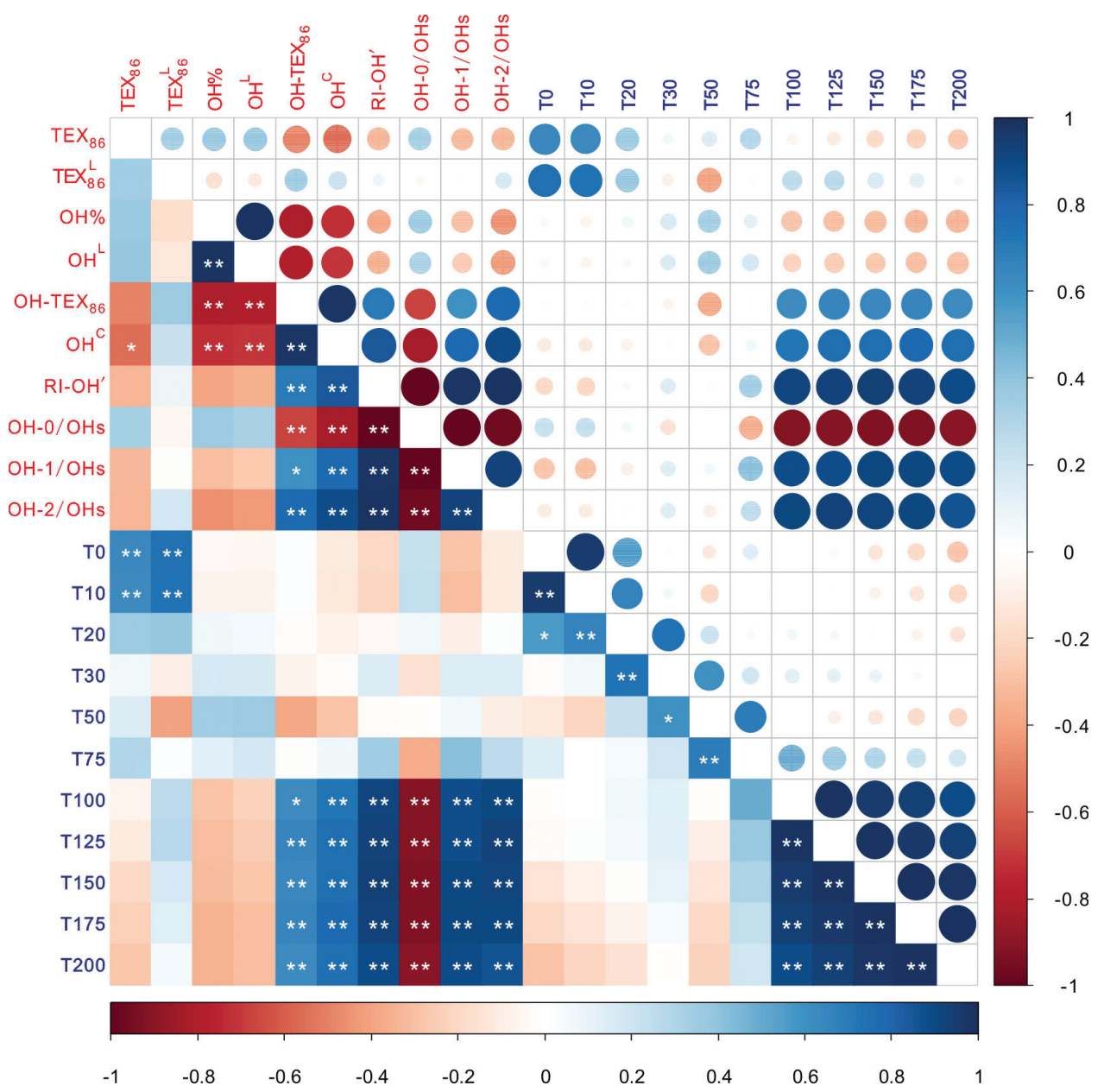

Fig. 6 Correlations between annual seawater temperatures at different depths and various indices based on iGDGTs and OH-GDGTs. T0-T200 represent seawater temperatures at different water depths from 0 to $200 \mathrm{~m}$. The size and colour represent the positive, negative and magnitude of correlation coefficients. A single asterisk indicates statistical significance at the 0.05 level for a two-tailed test. Double asterisks indicate statistical significance at the 0.01 level for a two-tailed test.

Every fractional abundance of OH-GDGTs varies with SOT. The $\mathrm{OH}-\mathrm{O} / \mathrm{OHs}$ is negatively correlated with SOT, while $\mathrm{OH}-1 / \mathrm{OHs}$ and $\mathrm{OH}-2 / \mathrm{OHs}$ are positively correlated with SOT. For OH-GDGT-based indices, correlations with annual SOT were higher than those with seasonally averaged SOT (Fig. 7), indicating the suitability of these indices as indicators of annual SOT. The strong correlations between RI-OH', OH-O/OHs and SOT highlight the potential to reconstruct SOT in Prydz Bay using $\mathrm{OH}-0$, which is more abundant than $\mathrm{OH}-1$ and $\mathrm{OH}-2$ in the colder waters of the polar regions (Fig. 8). Conversely, $\mathrm{OH}-2 / \mathrm{OHs}$ may be more suitable as an SST proxy in the tropical South China Sea where SST is above $25^{\circ} \mathrm{C}$ (Yang et al. 2018). The calibration equations relating SOT $(100-200 \mathrm{~m})$ to $\mathrm{RI}-\mathrm{OH}^{\prime}$ and $\mathrm{OH}-0 /$ OHs obtained from least-squares regression are:

$$
\begin{gathered}
\mathrm{OH}-0 / \mathrm{OHs}=-0.1636 \times \mathrm{SOT}+0.6138 ; \\
R^{2}=0.86, n=16, p<0.01(1) \\
\mathrm{RI}-\mathrm{OH}^{\prime}=0.2210 \times \mathrm{SOT}+0.5061 ; R^{2}=0.86, \\
n=16, p<0.01(2)
\end{gathered}
$$

The analytical errors were 0.03 and $0.02{ }^{\circ} \mathrm{C}$ for $\mathrm{OH}-0 /$ $\mathrm{OHs}$ and RI-OH', respectively, and the calibration errors of $\mathrm{OH}-0 / \mathrm{OHs}$ and $\mathrm{RI}-\mathrm{OH}^{\prime}$ were 0.15 and $0.14{ }^{\circ} \mathrm{C}$, respectively. Equations 1 and 2 were obtained from a limited number of samples over a narrow temperature range; further examination and validation are therefore warranted.

Possible mechanisms underlying relationships between OH-GDGT-based indices and SOT. Archaeal habitats and production mechanisms may underlie the relationship between seawater temperature and 


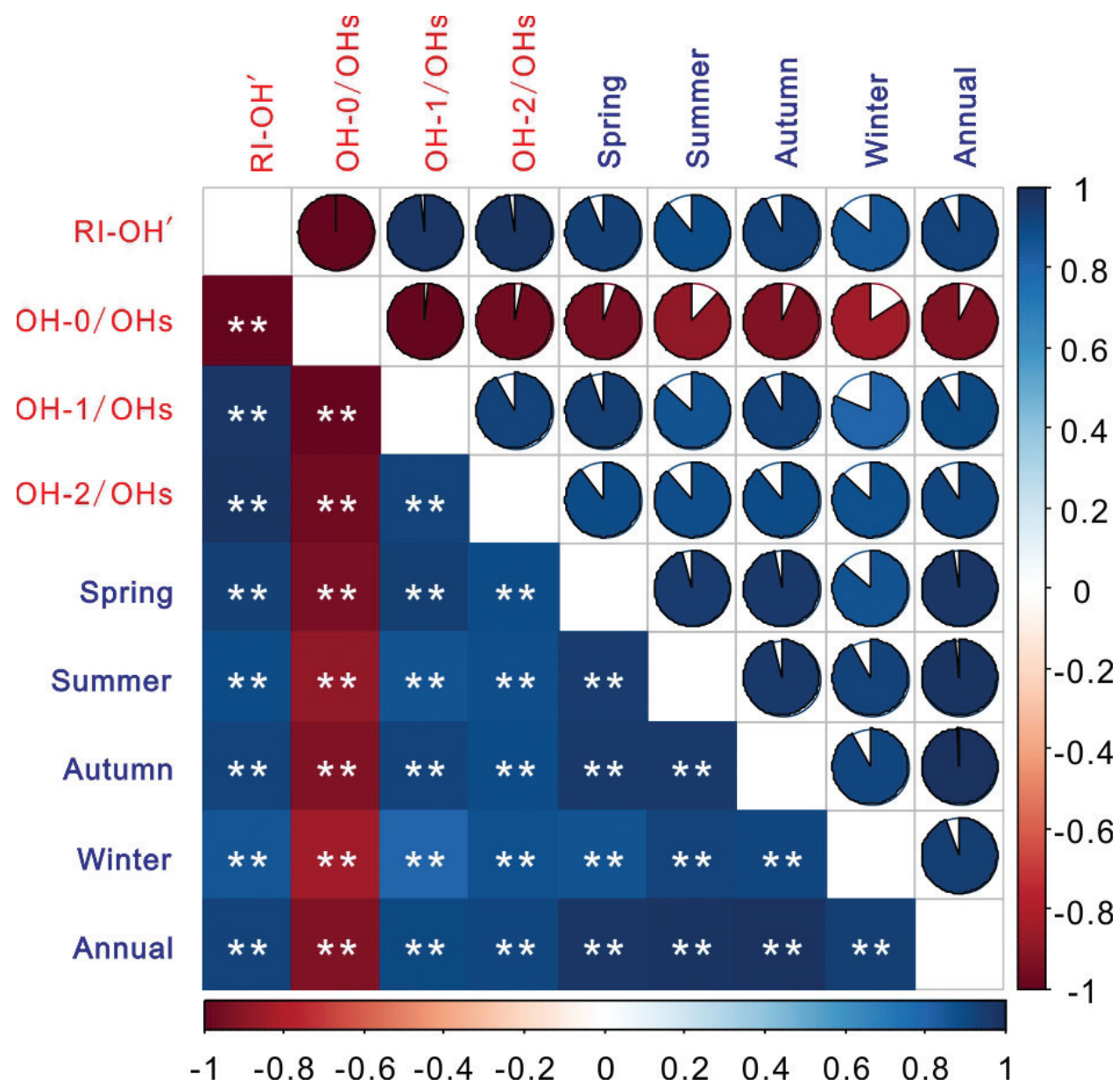

Fig. 7 Correlations between OH-GDGT-based indices with seasonal and annual SOT (100-200 m). The ratio and colour represent the positive, negative and magnitude of correlation coefficients. Double asterisks indicate statistical significance at the 0.01 level for a two-tailed test.

indices based on OH-GDGTs. All of the OH-GDGT-based indices showed stronger correlations with annual SOT $(100-200 \mathrm{~m})$ than annual SST, suggesting that OH-GDGTs may be mainly produced by planktonic Thaumarchaeota in subsurface waters. However, in Prydz Bay, archaeal abundance and diversity have only been studied in the water column of $5 \mathrm{~m}$ below sea ice (Ma et al. 2014). There is no information on archaeal abundance and diversity at other depths.

Studies conducted in other parts of Antarctica reported that archaea, dominated by Thaumarchaeota, are a significant component of the Antarctic picoplankton community in subsurface waters (Massana et al. 1998; Murray et al. 1999). In the Palmer Basin, archaeal rRNA maxima were found in subsurface (depths less than $100 \mathrm{~m}$ ) waters (Murray et al. 1998). In the Gerlache Strait (Antarctic Peninsula), relative abundances of archaeal rRNA were clearly higher at greater depths than at the surface (Massana et al. 1998). In the western region of the Antarctic Peninsula and in McMurdo Sound (Ross Sea), archaeal rRNA abundances were lower in surface waters and higher at depths greater than $150 \mathrm{~m}$ (Murray et al. 1999). West of the Antarctic Peninsula, the abundance of Group I Archaea was higher than that of Group II Archaea and, below $150 \mathrm{~m}$, the abundance of Group I Archaea increased with depth (Church et al. 2003). In the same region, archaeal abundance was low in Antarctic Summer Surface Water (0-45 m) and higher in remnant Winter Water (45-105 m in summer) (Kalanetra et al. 2009). These studies have shown that archaeal abundance maxima are in subsurface waters, and vertical distribution (i.e., depth profiles) of archaeal abundance varies among different regions.

The Margalef abundance index of bacteria was higher at $50 \mathrm{~m}$ water depth than that at 100 and $200 \mathrm{~m}$ (Wu et al. 2014). Moreover, the archaeal abundance maximum generally lies in deeper waters than bacteria (Church et al. 2003; Kirchman et al. 2007). Hence, it is possible that in Prydz Bay, the archaeal abundance maximum 

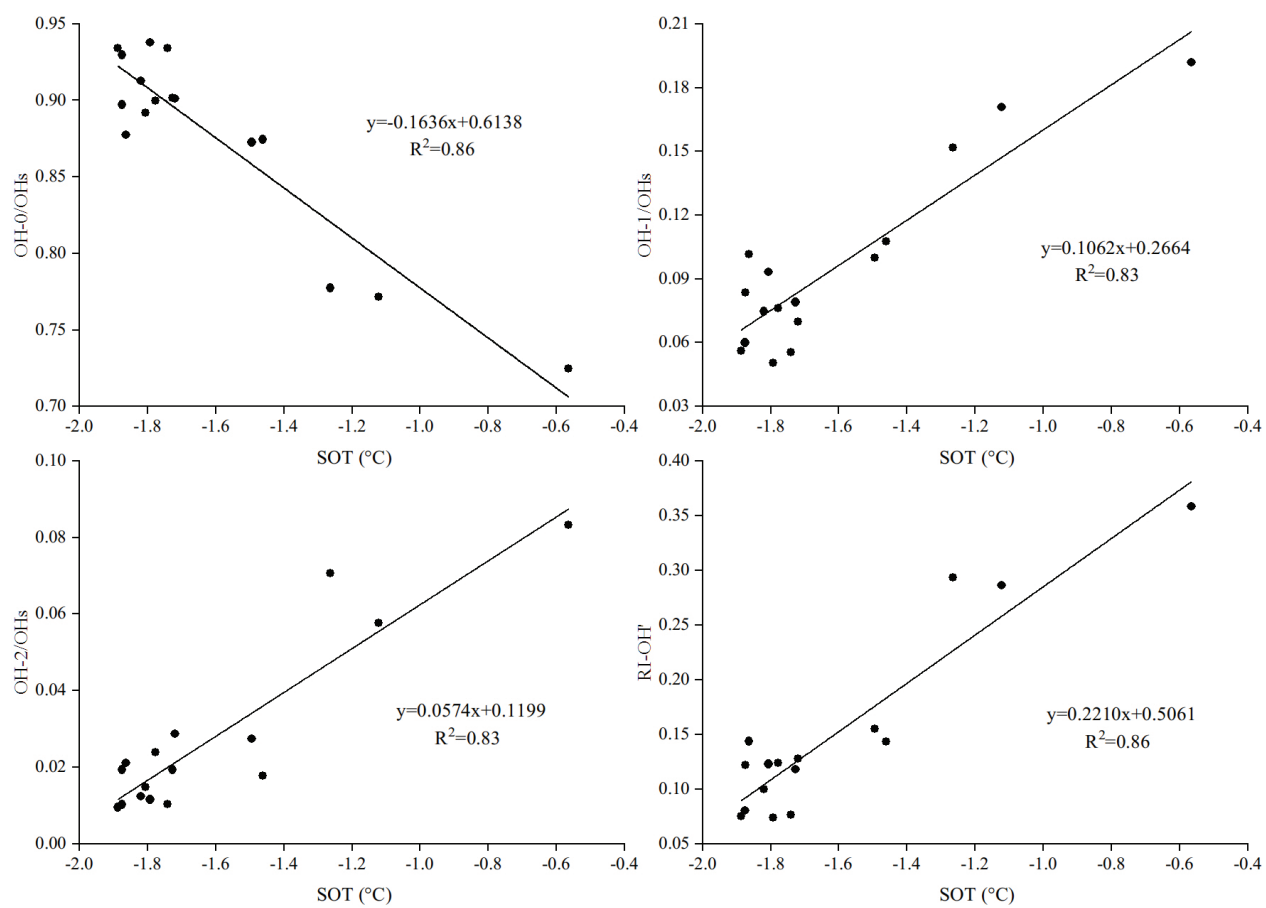

Fig. 8 Cross plots showing correlations between various OH-GDGT-based indices and SOT (100-200 m).

lies over depths of 100-200 m. In the Antarctic Peninsula, Etourneau et al. (2019) assumed that archaea mostly reside in the upper ocean, which is susceptible to intrusions of relatively warm water, especially CDW. The archaeal abundance maximum appears at the same time as the intrusion of CDW during the late winter and early spring when sea ice retreats; thus, GDGT-based temperatures could reflect a SOT influenced by warm water intrusion. In Prydz Bay, CDW upwells onto the continental shelf along troughs at the continental shelf break, allowing mCDW (warm water) to invade into Prydz Bay southward to Ice Shelf at intermediate depths (Herraiz-Borreguero et al. 2015). Therefore, archaeal growth in subsurface water might be associated with $\mathrm{CDW} / \mathrm{mCDW}$ in our study area. However, more work on the linkage between archaeal biology and ecology, GDGT synthesis, and the relatively warm waters in Prydz Bay and other parts of the polar regions is necessary to obtain a better understanding of variability and applicability of indices based on OH-GDGTs.

\section{Conclusions}

Our study detected iGDGTs, OH-GDGTs and brGDGTs in surface sediments of Prydz Bay, East Antarctica. All GDGTs were likely produced in situ. Concentrations of iGDGTs, OH-GDGTs and brGDGTs showed a similar spatial distribution, decreasing from the continental shelf to the deep ocean. Compared with iGDGT-based indices, OH-GDGTbased indices showed greater potential as a tool to reconstruct seawater temperatures in Prydz Bay. Since archaea seem to be most abundant in subsurface seawater, the $\mathrm{RI}-\mathrm{OH}^{\prime}$ and $\mathrm{OH}-\mathrm{O} / \mathrm{OHs}$ indices hold promise as tools to reconstruct annual SOT (100-200 m) in our study area and potentially in other parts of the polar regions.

\section{Acknowledgements}

The authors would like to thank the crews of CHINARE 29 and RV Xuelong for their help in collecting sediment samples. They are grateful to Zhongqiang Ji, Wenshen Chen and Chenjun Ye for their help with the experiments. Furthermore, they sincerely thank the Subject Editor and two anonymous reviewers for their constructive comments and suggestions.

\section{Disclosure statement}

No potential conflicts of interest were reported by the authors.

\section{Funding}

This study was funded by the National Natural Science Foundation of China (grant nos. 41976227, 41976228, 
41576186 and 41376193) and the Scientific Research Fund of the Second Institute of Oceanography, Ministry of Natural Resources (grant nos. JG1404 and JG1805), The Response and Feedback of the Southern Ocean to Climate Change (RFSOCC2020-2025) programme.

\section{References}

Blaga C.I., Reichart G.J., Heiri O. \& Sinninghe Damsté J.S. 2009. Tetraether membrane lipid distributions in water-column particulate matter and sediments: a study of 47 European lakes along a north-south transect. Journal of Paleolimnology 41, 523-540, doi: 10.1007/s10933-008-9242-2.

Brinkmeyer R., Knittel K., Jurgens J., Weyland H., Amann R. \& Helmke E. 2003. Diversity and structure of bacterial communities in Arctic versus Antarctic pack ice. Applied and Environmental Microbiology 69, 6610-6619, doi: 10.1128/AEM.69.11.6610.

Church M.J., DeLong E.F., Ducklow H.W., Karner M.B., Preston C.M. \& Karl D.M. 2003. Abundance and distribution of planktonic Archaea and Bacteria in the waters west of the Antarctic Peninsula. Limnology and Oceanography 48, 1893-1902, doi: 10.4319/lo.2003.48.5.1893.

Cooper A.K. \& O'Brien P.E. 2004. Leg 188 synthesis: transitions in the glacial history of the Prydz Bay region, East Antarctica, from ODP drilling. Proceedings of the Ocean Drilling Program: Scientific Results 188, 1-42, doi: 10.2973/odp. proc.sr.188.001.2004.

Cowie R.O.M., Maas E.W. \& Ryan K.G. 2011. Archaeal diversity revealed in Antarctic sea ice. Antarctic Science 23, 531-536, doi: 10.1017/S0954102011000368.

Doney S.C., Ruckelshaus M., Emmett Duffy J., Barry J.P., Chan F., English C.A., Galindo H.M., Grebmeier J.M., Hollowed A.B., Knowlton N., Polovina J., Rabalais N.N., Sydeman W.J. \& Talley L.D. 2012. Climate change impacts on marine ecosystems. Annual Review of Marine Science 4, 11-37, doi: 10.1146/annurev-marine-041911-111611.

Etourneau J., Collins L.G., Willmott V., Kim J.H., Barbara L., Leventer A., Schouten S., Sinninghe Damsté J.S., Bianchini A., Klein V., Crosta X. \& Massé G. 2013. Holocene climate variations in the western Antarctic Peninsula: evidence for sea ice extent predominantly controlled by changes in insolation and ENSO variability. Climate of the Past 9, 1431-1446, doi: 10.5194/cp-9-1431-2013.

Etourneau J., Sgubin G., Crosta X., Swingedouw D., Willmott V., Barbara L., Houssais M.N., Schouten S., Sinninghe Damsté J.S., Goosse H., Escutia C., Crespin J., Massé G. \& Kim J.H. 2019. Ocean temperature impact on ice shelf extent in the eastern Antarctic Peninsula. Nature Communications 10, article no. 304, doi: 10.1038/ s41467-018-08195-6.

Fietz S., Ho S.L., Huguet C., Rosell-Melé A. \& Martínez-García A. 2016. Appraising GDGT-based seawater temperature indices in the Southern Ocean. Organic Geochemistry 102, 93-105, doi: 10.1016/j.orggeochem.2016.10.003.

Fietz S., Huguet C., Bendle J., Escala M., Gallacher C., Herfort L., Jamieson R., Martínez-Garcia A., McClymont
E.L., Peck V.L., Prahl F.G., Rossi S., Rueda G., Sanson-Barrera A. \& Rosell-Melé A. 2012. Co-variation of crenarchaeol and branched GDGTs in globally-distributed marine and freshwater sedimentary archives. Global and Planetary Change 92-93, 275-285, doi: 10.1016/j.gloplacha.2012.05.020.

Fietz S., Huguet C., Rueda G., Hambach B. \& Rosell-Melé A. 2013. Hydroxylated isoprenoidal GDGTs in the Nordic seas. Marine Chemistry 152, 1-10, doi: 10.1016/j. marchem.2013.02.007.

Frölicher T.L., Sarmiento J.L., Paynter D.J., Dunne J.P., Krasting J.P. \& Winton M. 2015. Dominance of the Southern Ocean in anthropogenic carbon and heat uptake in CMIP5 models. Journal of Climate 28, 862-886, doi: 10.1175/JCLI-D-14-00117.1.

Gasparon M. \& Matschullat J. 2006. Geogenic sources and sinks of trace metals in the Larsemann Hills, East Antarctica: natural processes and human impact. Applied Geochemistry 21, 318-334, doi: 10.1016/j.apgeochem.2005.09.013.

Gruber N., Gloor M., Fletcher S.E.M., Doney S.C., Dutkiewicz S., Follows M.J., Gerber M., Jacobson A.R., Joos F., Lindsay K., Menemenlis D. \& Mouchet A. 2009. Oceanic sources, sinks, and transport of atmospheric $\mathrm{CO}_{2}$. Global Biogeochemical Cycles 23, GB1005, doi: 10.1029/2008GB003349.

Harris P.T., Taylor F., Pushina Z., Leitchenkov G. \& OBrien P.E., Smirnov V. 1998. Lithofacies distribution in relation to the geomorphic provinces of Prydz Bay, East Antarctica. Antarctic Science 10, 227-235, doi: 10.1017/ S0954102098000327.

Herraiz-Borreguero L., Coleman R., Allison I., Rintoul S.R., Craven M. \& Williams G.D. 2015. Circulation of modified circumpolar deep water and basal melt beneath the Amery Ice Shelf, East Antarctica. Journal of Geophysical ResearchOceans 120, 3098-3112, doi: 10.1002/2015JC010697.

Ho S.L., Mollenhauer G., Fietz S., Martínez-Garcia A., Lamy F., Rueda G., Schipper K., Méheust M., Rosell-Melé A., Stein R. \& Tiedemann R. 2014. Appraisal of TEX ${ }_{86}$ and TEX $\mathrm{TE}_{86}^{\mathrm{L}}$ thermometries in subpolar and polar regions. Geochimica et Cosmochimica Acta 131, 213-226, doi: 10.1016/j.gca.2014.01.001.

Huguet C., de Lange G.J., Gustafsson Ö., Middelburg J.J., Sinninghe Damsté J.S. \& Schouten S. 2008. Selective preservation of soil organic matter in oxidized marine sediments (Madeira Abyssal Plain). Geochimica et Cosmochimica Acta 72, 6061-6068, doi: 10.1016/j.gca.2008.09.021.

Huguet C., Fietz S. \& Rosell-Melé A. 2013. Global distribution patterns of hydroxy glycerol dialkyl glycerol tetraethers. Organic Geochemistry 57, 107-118, doi: 10.1016/j. orggeochem.2013.01.010.

Kaiser J. \& Arz H.W. 2016. Sources of sedimentary biomarkers and proxies with potential paleoenvironmental significance for the Baltic Sea. Continental Shelf Research 122, 102-119, doi: 10.1016/j.csr.2016.03.020.

Kalanetra K.M., Bano N. \& Hollibaugh J.T. 2009. Ammonia-oxidizing archaea in the Arctic Ocean and Antarctic coastal waters. Environmental Microbiology 11, 2434-2445, doi: 10.1111/j.1462-2920.2009.01974.x.

Kim J.H., Crosta X., Willmott V., Renssen H., Bonnin J., Helmke P., Schouten S. \& Sinninghe Damsté J.S. 2012. Holocene subsurface temperature variability in the eastern 
Antarctic continental margin. Geophysical Research Letters 39, 2010-2011, doi: 10.1029/2012GL051157.

Kim J.H., van der Meer J., Schouten S., Helmke P., Willmott V., Sangiorgi F., Koç N., Hopmans E.C. \& Sinninghe Damsté J.S. 2010. New indices and calibrations derived from the distribution of crenarchaeal isoprenoid tetraether lipids: implications for past sea surface temperature reconstructions. Geochimica et Cosmochimica Acta 74, 4639-4654, doi: 10.1016/j.gca.2010.05.027.

Kirchman D.L., Elifantz H., Dittel A.I., Malmstrom R.R. \& Cottrell M.T. 2007. Standing stocks and activity of archaea and bacteria in the western Arctic Ocean. Limnology and Oceanography 52, 495-507, doi: 10.4319/lo.2007.52.2.0495.

Kremer A., Stein R., Fahl K., Ji Z., Yang Z., Wiers S., Matthiessen J., Forwick M., Löwemark L., O’Regan M., Chen J. \& Snowball I. 2018. Changes in sea ice cover and ice sheet extent at the Yermak Plateau during the last $160 \mathrm{ka}-$ reconstructions from biomarker records. Quaternary Science Reviews 182,93-108, doi: 10.1016/j.quascirev.2017.12.016.

Lipp J.S. \& Hinrichs K.U. 2009. Structural diversity and fate of intact polar lipids in marine sediments. Geochimica et Cosmochimica Acta 73, 6816-6833, doi: 10.1016/j.gca.2009.08.003.

Liu X.L., Lipp J.S., Simpson J.H., Lin Y.S., Summons R.E. \& Hinrichs K.U. 2012. Mono- and dihydroxyl glycerol dibiphytanyl glycerol tetraethers in marine sediments: identification of both core and intact polar lipid forms. Geochimica et Cosmochimica Acta 89, 102-115, doi: 10.1016/j.gca.2012.04.053.

Liu X.L., Summons R.E. \& Hinrichs K.U. 2012. Extending the known range of glycerol ether lipids in the environment: structural assignments based on tandem mass spectral fragmentation patterns. Rapid Communications in Mass Spectrometry 26, 2295-2302, doi: 10.1002/rcm.6355.

Locarnini R.A., Mishonov A.V., Antonov J.I., Boyer T.P., Garcia H.E., Baranova O.K., Zweng M.H., Paver C.R., Reagan J.R., Johnson D.R., Hamilton M. \& Seidov D. 2013. World Ocean atlas 2013. Vol. 1. Temperature. Silver Spring, MD: US Department of Commerce, National Oceanic and Atmospheric Administration.

Lü X., Liu X.L., Elling F.J., Yang H., Xie S., Song J., Li X., Yuan H., Li N. \& Hinrichs K.U. 2015. Hydroxylated isoprenoid GDGTs in Chinese coastal seas and their potential as a paleotemperature proxy for mid-to-low latitude marginal seas. Organic Geochemistry 89-90, 31-43, doi: 10.1016/j.orggeochem.2015.10.004.

Ma J., Du Z., Lu, W., Yu Y., Zeng Y., Chen B. \& Li H. 2014. Archaeal diversity and abundance within different layers of summer sea-ice and seawater from Prydz Bay, Antarctica. Advances in Polar Science 25, 54-60, doi: 10.13679/j.advps.2014.1.00054.

Massana R., Taylor, L.T., Murray, A.E., Wu, K.Y., Jeffrey, W.H. \& Delong, E.F.1998. Vertical distribution and temporal variation of marine planktonic archaea in the Gerlache Strait, Antarctica, during early spring. Limnology and Oceanography 43, 607-617, doi: 10.4319/lo.1998.43.4.0607.

Meijers A.J.S., Klocker A., Bindoff N.L., Williams G.D. \& Marsland,S.J. 2010. The circulation and water masses of the Antarctic shelf and continental slope between 30 and $80^{\circ}$ E. Deep-Sea Research Part II 57, 723-737, doi: 10.1016/j. dsr2.2009.04.019.
Müller P.J., Kirst G., Ruhland G., von Storch I. \& RosellMelé A. 1998. Calibration of the alkenone paleotemperature index $\mathrm{U}_{37}{ }^{{ }^{\prime}}$ based on core-tops from the eastern South Atlantic and the global ocean $\left(60^{\circ} \mathrm{N}-60^{\circ} \mathrm{S}\right)$. Geochimica et Cosmochimica Acta 62, 1757-1772, doi: 10.1016/ S0016-7037(98)00097-0.

Murray A.E., Preston C.M., Massana R., Taylor L.T., Blakis A. \& Wu K. 1998. Seasonal and spatial variability of bacterial and archaeal assemblages in the coastal waters near Anvers Island, Antarctica. Applied and Environmental Microbiology 6, 2585-2595, doi: 10.1128/AEM.64.7.2585-2595.1998.

Murray A.E., Wul K.Y., Moyer C.L. \& Kar D.M. 1999. Evidence for circumpolar distribution of planktonic archaea in the Southern Ocean. Aquatic Microbial Ecology 18, 263-273, doi: 10.3354/ame018263.

Nurnberg D. 2000. Taking the temperature of past ocean surfaces. Science 289, 1698-1699, doi: 10.1126/science.289.5485.1698.

Peterse F., Kim J.H., Schouten S., Kristensen D.K., Koç N. \& Sinninghe Damsté J.S. 2009. Constraints on the application of the MBT/CBT palaeothermometer at high latitude environments (Svalbard, Norway). Organic Geochemistry 40, 692-699, doi: 10.1016/j.orggeochem.2009.03.004.

$\mathrm{R}$ Core Team. 2018. $R$ : a language and environment for statistical computing. Vienna: R Foundation for Statistical Computing.

Rintoul S.R., Chown S.L., DeConto R.M., England M.H., Fricker H.A., Masson-Delmotte V., Naish T.R., Siegert M.J. \& Xavier J.C. 2018. Choosing the future of Antarctica. Nature 558, 233-241, doi: 10.1038/s41586-018-0173-4.

Roquet F., Williams G., Hindell M.A., Harcourt R., McMahon C., Guinet C., Charrassin J.B., Reverdin G., Boehme L., Lovell P. \& Fedak M. 2014. A Southern Indian Ocean database of hydrographic profiles obtained with instrumented elephant seals. Scientific Data 1, article no. 140028, doi: 10.1038/sdata.2014.28.

Sachs J., Pahnke K., Smittenberg R. \& Zhang Z. 2013. Biomarkers indicators of past climate. The Encyclopedia of Quaternary Science 2, 775-782, doi: 10.1016/B978-0-444-53643-3.00280-6.

Sarmiento J.L., Gruber N., Brzezinski M.A. \& Dunne J.P. 2004. High-latitude controls of thermocline nutrients and low latitude biological productivity. Nature 427, 56-60, doi: 10.1038/Nature02127.

Schlitzer R. 2015. Ocean data view. Version 4.7.3 downloaded from the internet at http://odv.awi.de on 8 August 2015.

Schouten S., Hopmans E.C., Schefuß E. \& Sinninghe Damsté J.S. 2002. Distributional variations in marine crenarchaeol membrane lipids: a new tool for reconstructing ancient sea water temperatures? Earth and Planetary Science Letters 204, 265-274, doi: 10.1016/S0012-821X(03)00193-6.

Schouten S., Hopmans E.C. \& Sinninghe Damsté J.S. 2013. The organic geochemistry of glycerol dialkyl glycerol tetraether lipids: a review. Organic Geochemistry 54, 19-61, doi: 10.1016/j.orggeochem.2012.09.006.

Shevenell A.E., Ingalls A.E., Domack E.W. \& Kelly C. 2011. Holocene Southern Ocean surface temperature variability west of the Antarctic Peninsula. Nature 470, 250-254, doi: 10.1038/nature09751.

Sinninghe Damsté J.S., Hopmans E.C., Pancost R.D., Schouten S. \& Geenevasen J.A.J. 2000. Newly discovered non-isoprenoid 
glycerol dialkyl glycerol tetraether lipids in sediments. Chemical Communications 31, 1683-1684, doi: 10.1039/b004517i.

Sinninghe Damsté J.S., Ossebaar J., Abbas B., Schouten S. \& Verschuren D. 2009. Fluxes and distribution of tetraether lipids in an equatorial African lake: constraints on the application of the $\mathrm{TEX}_{86}$ palaeothermometer and BIT index in lacustrine settings. Geochimica et Cosmochimica Acta 73, 4232-4249, doi: 10.1016/j.gca.2009.04.022.

Sinninghe Damsté J.S., Rijpstra W.I.C., Hopmans E.C., Weijers J.W.H., Foesel B.U., Overmann J. \& Dedysh S.N. 2011. 13,16-Dimethyl octacosanedioic acid (iso-diabolic acid), a common membrane-spanning lipid of Acidobacteria subdivisions 1 and 3. Applied and Environmental Microbiology 77, 4147-4154, doi: 10.1128/AEM.00466-11.

Sinninghe Damsté J.S., Schouten S., Hopmans E.C., van Duin A.C.T. \& Geenevasen J.A.J. 2002. Crenarchaeol: the characteristic core glycerol dibiphytanyl glycerol tetraether membrane lipid of cosmopolitan pelagic crenarchaeota. Journal of Lipid Research 43, 1641-1651, doi: 10.1194/jlr. M200148-JLR200.

Smith N.R. \& Treguer P. 1994. Physical and chemical oceanography in the vicinity of Prydz Bay, Antarctica. Cambridge: Cambridge University Press.

Smith N.R., Zhaoqian D., Kerry K.R. \& Wright S. 1984. Water masses and circulation in the region of Prydz Bay, Antarctica. Deep-Sea Research Part A 31, 1121-1147, doi: 10.1016/0198-0149(84)90016-5.

Sun W., Hu C., Han Z., Pan J. \& Weng H. 2012. Distribution of nutrients and Chla in Prydz Bay during the austral summer of 2011 . Chinese Journal of Polar Research 24, 178-186.

Takahashi T., Sutherland S.C., Sweeney C., Poisson A., Metzl N., Tilbrook B., Bates N., Wanninkhof R., Feely R.A., Sabine C., Olafsson J. \& Nojiri Y. 2002. Global sea-air $\mathrm{CO}_{2}$ flux based on climatological surface ocean $\mathrm{pCO}_{2}$, and seasonal biological and temperature effects. Deep-Sea Research Part II 49, 1601-1622, doi: 10.1016/S0967-0645(02)00003-6.

Taylor F. \& McMinn A. 2002. Late Quaternary diatom assemblages from Prydz Bay, Eastern Antarctica. Quaternary Research 57, 151-161, doi: 10.1006/qres.2001.2279.

Teske A. \& Sørensen K.B. 2008. Uncultured archaea in deep marine subsurface sediments: have we caught them all? ISME Journal 2, 3-18, doi: 10.1038/ismej.2007.90.

Tierney J.E. \& Russell J.M. 2009. Distributions of branched GDGTs in a tropical lake system: implications for lacustrine application of the MBT/CBT paleoproxy. Organic Geochemistry 40, 1032-1036, doi: 10.1016/j.orggeochem.2009.04.014.

Tierney J.E., Russell J.M., Eggermont H., Hopmans E.C., Verschuren D. \& Sinninghe Damsté J.S. 2010. Environmental controls on branched tetraether lipid distributions in tropical East African lake sediments. Geochimica et Cosmochimica Acta 74, 4902-4918, doi: 10.1016/j.gca.2010.06.002.

Turner J., Barrand N.E., Bracegirdle T.J., Convey P., Hodgson D.A., Jarvis M., Jenkins A., Marshall G., Meredith M.P., Roscoe H., Shanklin J., French J., Goosse H., Guglielmin M., Gutt J., Jacobs S., Kennicutt M.C., MassonDelmotte V., Mayewski P., Navarro F., Robinson S., Scambos T., Sparrow M., Summerhayes C., Speer K. \& Klepikov A. 2014. Antarctic climate change and the environment: an update. Polar Record 50, 237-259, doi: 10.1017/S0032247413000296.
Vaz R.A.N. \& Lennon G.W. 1996. Physical oceanography of the Prydz Bay region of Antarctic waters. Deep-Sea Research Part I 43, 603-641, doi: 10.1016/0967-0637(96)00028-3.

Wang H., Chen Z., Wang K., Liu H., Tang Z. \& Huang Y. 2015. Characteristics of heavy minerals and grain size of surface sediments on the continental shelf of Prydz Bay: implications for sediment provenance. Antarctic Science 28, 103-114, doi: 10.1017/s0954102015000498.

Wang S., Wang R., Chen J., Chen Z., Cheng Z., Wang W. \& Huang Y. 2013. Spatial distribution patterns of GDGTs in the surface sediments from the Bering Sea and Arctic Ocean and their environmental significances. Advances in Earth Science 28, 282-296, doi: 10.11867/j.issn.1001-8166.2013.02.0282.

Weijers J.W.H., Panoto E., van Bleijswijk J., Schouten S., Rijpstra W.I.C., Balk M., Stams A.J.M. \& Sinninghe Damsté J.S. 2009. Constraints on the biological source(s) of the orphan branched tetraether membrane lipids. Geomicrobiology Journal 26, 402-414, doi: 10.1080/01490450902937293.

Weijers J.W.H., Schouten S., Spaargaren O.C. \& Sinninghe Damsté J.S. 2006. Occurrence and distribution of tetraether membrane lipids in soils: implications for the use of the TEX ${ }_{86}$ proxy and the BIT index. Organic Geochemistry 37, 1680-1693, doi: 10.1016/j.orggeochem.2006.07.018.

Williams G.D., Herraiz-Borreguero L., Roquet F., Tamura T., Ohshima K.I., Fukamachi Y., Fraser A.D., Gao L., Chen H., McMahon C.R., Harcourt R. \& Hindell M. 2016. The suppression of Antarctic bottom water formation by melting ice shelves in Prydz Bay. Nature Communications 7, 1-9, doi: 10.1038/ncomms 12577.

Worby A.P., Massom R.A., Allison I., Lytle V.I. \& Heil P. 1998. East Antarctic sea ice: a review of its structure, properties and drift. Antarctic Sea Ice Properties, Processes and Variability 74, 41-67, doi: 10.1029/AR074p0041.

Wu L., Wang R., Xiao W., Ge S., Chen Z. \& Krijgsman W. 2017. Productivity-climate coupling recorded in Pleistocene sediments off Prydz Bay (East Antarctica). Palaeogeography, Palaeoclimatology, Palaeoecology 485, 260-270, doi: 10.1016/j.palaeo.2017.06.018.

Wu Y., Han Z., Zhang X., Zhou Y., Wu M. \& Xu X. 2014. Community composition of Antarctic bacterioplankton isolated from the Prydz Bay, Antarctica. Chinese Journal of Polar Research 26, 222-229.

Xiao W., Wang Y., Zhou S., Hu L., Yang H. \& Xu Y. 2016. Ubiquitous production of branched glycerol dialkyl glycerol tetraethers (brGDGTs) in global marine environments: a new source indicator for brGDGTs. Biogeosciences 13, 5883-5894, doi: 10.5194/bg-13-5883-2016.

Yabuki T., Suga T., Hanawa K., Matsuoka K., Kiwada H. \& Watanabe T. 2006. Possible source of the Antarctic Bottom Water in the Prydz Bay region. Journal of Oceanography 62, 649-655, doi: 10.1007/s 10872-006-0083-1.

Yang Y., Gao C., Dang X., Ruan X., Lü X., Xie S., Li X., Yao Y. \& Yang H. 2018. Assessing hydroxylated isoprenoid GDGTs as a paleothermometer for the tropical South China Sea. Organic Geochemistry 115, 156-165, doi: 10.1016/j. orggeochem.2017.10.014.

Yu P., Hu C., Liu X., Pan J. \& Zhang H. 2009. Modern sedimentation rates in Prydz Bay, Antarctic. Acta Sedmentologica Sinica 27, 1172-1177. 